Rohit Gupta, MBBS, FCCP; Maulin Patel, MD; Luis Caceres, MD; Mayur Rali, MD, FAAFP; Parth Rali, MD

Department of Thoracic Medicine and Surgery, Lewis Katz School of Medicine at Temple University, Philadelphia, PA (Drs. Gupta, Patel, and Parth Rali); Department of Family Medicine, Barbara and Zucker School of Medicine at Hofstra/ Northwell - South Shore University Hospital, NY (Drs. Caceres and Mayur Rali)

تrohit.gupta@tuhs. temple.edu

The authors reported no potential conflict of interest relevant to this article. doi: $10.12788 /$ fp. 0177

\section{Sarcoidosis: An FP's primer on an enigmatic disease}

\section{PRACTICE RECOMMENDATIONS}

> Consider biopsy to aid in diagnosing sarcoidosis; it may be avoided with a high clinical suspicion for sarcoidosis (eg, Löfgren syndrome, lupus pernio, or Heerfordt syndrome). (C)

> Rule out alternative diagnoses such as infection, malignancy, collagen vascular disease, and vasculitis. (C)

\section{> Identify extra-pulmonary} organ involvement, as clinically indicated, by screening with a baseline eye examination; complete blood count; creatinine, alkaline phosphatase, and calcium levels; electrocardiogram, and other organ-specific studies. (C)

> Make a patient-centered decision whether to begin antiinflammatory treatment based on symptomatology and risk of organ failure or death. (c)

Strength of recommendation (SOR)

A Good-quality patient-oriented evidence

B Inconsistent or limited-quality patientoriented evidence

C Consensus, usual practice, opinion, disease-oriented evidence, case series
$\mathrm{S}$ arcoidosis is a multisystem inflammatory disease of unclear etiology that primarily affects the lungs. It can occur at any age but usually develops before the age of 50 years, with an initial peak incidence at 20 to 29 years and a second peak incidence after 50 years of age, especially among women in Scandinavia and Japan. ${ }^{1}$ Sarcoidosis affects men and women of all racial and ethnic groups throughout the world, but differences based on race, sex, and geography are noted. ${ }^{1}$

The highest rates are reported in northern European and African-American individuals, particularly in women. ${ }^{1,2}$ The adjusted annual incidence of sarcoidosis among African Americans is approximately 3 times that among White Americans ${ }^{3}$ and is more likely to be chronic and fatal in African Americans. ${ }^{3}$ The disease can be familial with a possible recessive inheritance mode with incomplete penetrance. ${ }^{4}$ Risk of sarcoidosis in monozygotic twins appears to be 80 times greater than that in the general population, which supports genetic factors accounting for two-thirds of disease susceptibility. ${ }^{5}$

\section{Likely factors}

in the development of sarcoidosis

The exact cause of sarcoidosis is unknown, but we have insights into its pathogenesis and potential triggers. ${ }^{1,6-9}$ Genes involved are being identified: class I and II human leukocyte antigen (HLA) molecules are most consistently associated with risk of sarcoidosis. Environmental exposures can activate the innate immune system and precondition a susceptible individual to react to potential causative antigens in a highly polarized, antigen-specific Thl immune response. The epithelioid granulomatous response involves local proinflammatory cytokine production and enhanced T-cell immunity at sites of inflammation. ${ }^{10}$ Granulomas generally form 
to confine pathogens, restrict inflammation, and protect surrounding tissue. ${ }^{11-13}$

ACCESS (A Case Control Etiologic Study of Sarcoidosis) identified several environmental exposures such as chemicals used in the agriculture industry, mold or mildew, and musty odors at work. ${ }^{14}$ Tobacco use was not associated with sarcoidosis. ${ }^{14}$ Recent studies have shown positive associations with service in the US Navy, ${ }^{15}$ metal working, ${ }^{16}$ firefighting, ${ }^{17}$ the handling of building supplies, ${ }^{18}$ and onsite exposure while assisting in rescue efforts at the World Trade Center disaster. ${ }^{19}$ Other data support the likelihood that specific environmental exposures associated with microbe-rich environments modestly increase the risk of sarcoidosis. ${ }^{14}$ Mycobacterial and propionibacterial DNA and RNA are potentially associated with sarcoidosis. ${ }^{20}$

\section{Clinical manifestations are nonspecific}

The diagnosis of sarcoidosis can be difficult and delayed due to diverse organ involvement and nonspecific presentations. TABLE $1^{21-31}$ shows the diverse manifestations in a patient with suspected sarcoidosis. Around $50 \%$ of the patients are asymptomatic. ${ }^{23,24}$ Sarcoidosis is a diagnosis of exclusion, starting with a detailed history to rule out infections, occupational or environmental exposures, malignancies, and other possible disorders (TABLE 2). ${ }^{22}$

\section{Diagnostic work-up}

The primary objective of a diagnostic evaluation in most suspected cases of sarcoidosis is to corroborate the clinical and radiologic features with pathologic evidence of nonnecrotizing granulomas and to exclude other causes of granulomatous inflammation. ${ }^{22}$

\section{Radiologic studies}

I Chest $\mathbf{x}$-ray (CXR) provides diagnostic and prognostic information in the evaluation of sarcoidosis using the Scadding classification system (FIGURE 1). ${ }^{21,25,32,33}$ Interobserver variability, especially between stages II and III and III and IV is the major limitation of this system. ${ }^{32}$ At presentation, radiographs are abnormal in approximately $90 \%$ of patients. ${ }^{34}$ Lymphadenopathy is the most common ra- diographic abnormality, occurring in more than two-thirds of cases, and pulmonary opacities (nodules and reticulation) with a middle to upper lobe predilection are present in $20 \%$ to $50 \%$ of patients. ${ }^{1,31,35}$ The nodules vary in size and can coalesce and cause alveolar collapse, thus producing consolidation. ${ }^{36}$ Linear opacities radiating laterally from the hilum into the middle and upper zones are characteristic in fibrotic disease.

I High-resolution computed tomography (HRCT). Micronodules in a perilymphatic distribution with upper lobe predominance combined with subcarinal and symmetrical hilar lymph node enlargement is practically diagnostic of sarcoidosis in the right clinical context. TABLE $3^{21,23,25,32}$ and FIGURE $2^{21,23,25,32}$ summarize the common CT chest findings of sarcoidosis.

I Advanced imaging such as (18)Ffluorodeoxyglucose positron emission tomography (PET) and magnetic resonance imaging (MRI) are used in specialized settings for advanced pulmonary, cardiac, or neurosarcoidosis.

\section{Tissue biopsy}

Skin lesions (other than erythema nodosum), eye lesions, and peripheral lymph nodes are considered the safest extrapulmonary locations for biopsy. ${ }^{21,25}$ If pulmonary infiltrates or lymphadenopathy are present, or if extrapulmonary biopsy sites are not available, then flexible bronchoscopy with biopsy is the mainstay for tissue sampling. ${ }^{25}$

Bronchoalveolar lavage (BAL), transbronchial biopsy (TBB), endobronchial biopsy (EBB), and endobronchial ultrasound (EBUS) are invaluable modalities that have reduced the need for open lung biopsy. BAL in sarcoidosis can show lymphocytosis $>15 \%$ (nonspecific) and a CD4:CD8 lymphocyte ratio $>3.5$ (specificity $>90 \%$ ). ${ }^{21,22}$ TBB is more sensitive than EBB; however, sensitivity overall is heightened when both of them are combined. The advent of EBUS has increased the safety and efficiency of needle aspiration of mediastinal lymph nodes. Diagnostic yield of EBUS $(\sim 80 \%)$ is superior to that with TBB and EBB ( $50 \%)$, especially in stage I and II sarcoidosis. ${ }^{37}$ The combination of EBUS with TBB improves the diagnostic yield to $\sim 90 \%{ }^{37}$
Sarcoidosis is a diagnosis of exclusion; one must rule out infections, occupational or environmental exposures, malignancies, and other disorders that cause granulomatous inflammation. 


\section{TABLE 1}

\section{Clinical manifestations of sarcoidosis ${ }^{21-31}$}

\begin{tabular}{|c|c|c|c|c|}
\hline $\begin{array}{l}\text { Organ } \\
\text { system }\end{array}$ & Prevalence & Clinical manifestations & Symptoms & Comments \\
\hline Lungs & $90 \%{ }^{23}$ & $\begin{array}{l}\text { Bilateral hilar lymphadenopathy (LN) is } \\
\text { most common; mediastinal LN, fibrotic lung } \\
\text { disease, pulmonary hypertension }{ }^{21,23,25} \\
\text { Rare: pleural effusion, pneumothorax, } \\
\text { necrotizing sarcoid angiitis, granulomatosis }{ }^{25}\end{array}$ & $\begin{array}{l}\text { Dyspnea, dry } \\
\text { cough, chest pain, } \\
\text { wheezing }^{23,24,26}\end{array}$ & $\begin{array}{l}\text { Löfgren syndrome: triad of } \\
\text { hilar adenopathy, erythema } \\
\text { nodosum, arthralgias }{ }^{23,25}\end{array}$ \\
\hline Skin & $\begin{array}{l}25 \%- \\
30 \% 23,27\end{array}$ & $\begin{array}{l}\text { Specific skin lesions (granulomatous) - } \\
\text { macules/papules are most common; plaque, } \\
\text { lupus pernio, Darier Roussy lesion }{ }^{27} \\
\text { Nonspecific inflammatory lesions - erythema } \\
\text { nodosum, calcinosis cutis, clubbing, and } \\
\text { neutrophilic dermatosis }\end{array}$ & Painful, pruritic rashes ${ }^{27}$ & $\begin{array}{l}\text { More common in African } \\
\text { Americans and women }{ }^{23} \\
\text { Specific skin lesions have } \\
\text { predilection to tattoos and } \\
\text { scars }\end{array}$ \\
\hline $\begin{array}{l}\text { Liver and } \\
\text { spleen }\end{array}$ & $\begin{array}{l}\text { Variable } \\
\text { across } \\
\text { studies }^{23}\end{array}$ & $\begin{array}{l}\text { Liver: asymptomatic elevation of liver } \\
\text { enzymes (most common) } \\
\text { Rare: intrahepatic cholestatic syndrome, } \\
\text { portal hypertension, hepatopulmonary } \\
\text { syndrome, cirrhosis } \\
\text { Spleen: splenomegaly, rarely pancytopenia }{ }^{23}\end{array}$ & $\begin{array}{l}\text { Fever, nausea, pruritis, } \\
\text { abdominal pain, } \\
\text { vomiting, anorexia, } \\
\text { weight loss }{ }^{24}\end{array}$ & $\begin{array}{l}\text { ACCESS data reported } \\
\text { incidence of hepatic and } \\
\text { splenic sarcoid at } 11 \% \text { and } \\
7 \% \text {, respectively } 31\end{array}$ \\
\hline Eyes & $20 \%-50 \%^{22}$ & $\begin{array}{l}\text { Anterior uveitis (most common); chronic } \\
\text { form leads to glaucoma } \\
\text { Posterior uveitis } \\
\text { Occasionally both anterior/posterior uveitis }{ }^{29}\end{array}$ & $\begin{array}{l}\text { Eye pain, red eyes, } \\
\text { blurry vision, floaters, } \\
\text { photophobia, visual } \\
\text { loss }^{25,30}\end{array}$ & More common in women 31 \\
\hline Renal & & $\begin{array}{l}\text { Renal failure due to granulomatous } \\
\text { nephritis can occur } 22,24\end{array}$ & $\begin{array}{l}\text { Hematuria, abdominal } \\
\text { pain }\end{array}$ & \\
\hline $\begin{array}{l}\text { Calcium } \\
\text { disorders }\end{array}$ & $\begin{array}{l}10 \%- \\
40 \%^{21,23,25}\end{array}$ & $\begin{array}{l}\text { Asymptomatic hypercalciuria (most } \\
\text { common), hypercalcemia, renal calculi } 22,25\end{array}$ & & \\
\hline $\begin{array}{l}\text { Nervous } \\
\text { system }\end{array}$ & $5 \%-13 \% 23$ & $\begin{array}{l}\text { Facial nerve palsy and aseptic meningitis } \\
\text { (most common), diabetes insipidus, } \\
\text { cognitive dysfunction, hypopituitarism, } \\
\text { polyneuropathy, small fiber neuropathy, } \\
\text { spinal cord disorders, hydrocephalus, } \\
\text { seizures } \\
22,23,24,28\end{array}$ & $\begin{array}{l}\text { Headache, altered } \\
\text { mentation, cranial } \\
\text { nerve palsies }{ }^{23,24,28}\end{array}$ & More common in women 23 \\
\hline $\begin{array}{l}\text { Musculo- } \\
\text { skeletal }\end{array}$ & $13 \%^{23}$ & $\begin{array}{l}\text { Chronic arthralgias (most common), arthritis, } \\
\text { proximal muscle weakness, myalgias, } \\
\text { intramuscular nodules }{ }^{22,25}\end{array}$ & $\begin{array}{l}\text { Mostly asymptomatic, } \\
\text { bone/muscle pain }\end{array}$ & \\
\hline Heart & $5 \%{ }^{23,25}$ & $\begin{array}{l}\text { Most affected locations are left ventricular } \\
\text { free wall and intraventricular septum (with } \\
\text { the conducting system); hence, can manifest } \\
\text { with bundle branch block, atrioventricular } \\
\text { block, ventricular tachycardia, ventricular } \\
\text { fibrillation, congestive heart failure, } \\
\text { pericarditis, and sudden cardiac death } \\
\text { 21,25 }\end{array}$ & $\begin{array}{l}\text { Syncope, palpitations, } \\
\text { chest pain, sudden } \\
\text { death, heart failure } 23,24\end{array}$ & $\begin{array}{l}\text { Prevalence is around } \\
25 \% \text { in autopsy studies, } \\
\text { indicating that the majority } \\
\text { of cardiac involvement is } \text { silent }^{30}\end{array}$ \\
\hline $\begin{array}{l}\text { Parotid } \\
\text { glands }\end{array}$ & $<6 \%^{22}$ & $\begin{array}{l}\text { As part of Heerfordt syndrome or can } \\
\text { manifest in isolation }{ }^{22}\end{array}$ & Swelling in parotid area & $\begin{array}{l}\text { Heerfordt triad: fever, } \\
\text { parotitis, uveitis }{ }^{22,28}\end{array}$ \\
\hline \multirow[b]{2}{*}{ Blood } & $4 \%^{22}$ & Leukopenia & - & Rare \\
\hline & $22 \%{ }^{22}$ & Anemia & $\begin{array}{l}\text { Fatigue, exertional } \\
\text { dyspnea, weakness }\end{array}$ & \\
\hline
\end{tabular}

ACCESS, A Case Control Etiologic Study of Sarcoidosis. 
TABLE 2

Differential diagnosis of sarcoidosis ${ }^{22}$

\begin{tabular}{|c|c|}
\hline Condition & Possible causes \\
\hline Collagen vascular disease & $\begin{array}{l}\text { Systemic lupus erythematosus, Sjögren syndrome, primary biliary cirrhosis, } \\
\text { familial granulomatous arthritis }\end{array}$ \\
\hline Drug-induced granulomatous disease & Anti-TNF therapy, other biologics, BCG therapy, methotrexate \\
\hline Environmental/occupational exposure & $\begin{array}{l}\text { Beryllium, silica, aluminum, cobalt, talc, titanium, etc; hypersensitivity } \\
\text { pneumonitis }\end{array}$ \\
\hline Infection & $\begin{array}{l}\text { Fungal: histoplasma, blastomyces, coccidioidomyces, cryptococcus, Aspergillus } \\
\text { Bacterial: Brucella, nontuberculous and tuberculous mycobacteria } \\
\text { Parasitic: echinococcus, leishmania, schistosomiasis } \\
\text { Viral: HIV }\end{array}$ \\
\hline Malignancy & Lymphoma, lung carcinoma, carcinoid tumor, testicular cancer \\
\hline Vasculitis & $\begin{array}{l}\text { Wegener granulomatosis, giant cell arteritis, Takayasu arteritis, Churg Strauss } \\
\text { syndrome }\end{array}$ \\
\hline Miscellaneous & $\begin{array}{l}\text { Crohn disease, common variable immunodeficiency, immune reconstitution } \\
\text { inflammatory syndrome }\end{array}$ \\
\hline
\end{tabular}

BCG, Bacillus Calmette-Guerin; TNF, tumor necrosis factor.

\section{FIGURE 1}

Stages of sarcoidosis on chest $\mathrm{x}-$ ray $^{21,25,32,33}$

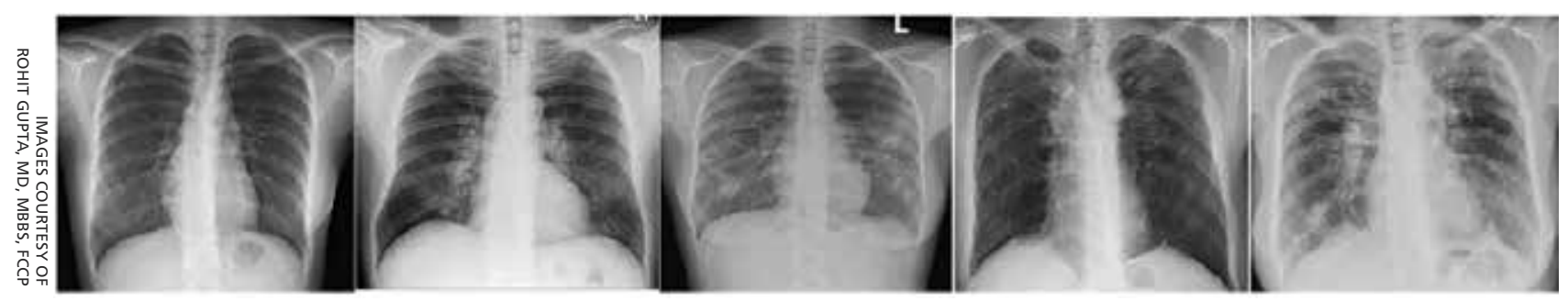

From left to right: Scadding stages 0, I, II, III, IV of sarcoidosis on chest x-ray. Stage 0: normal. Stage I: bilateral hilar adenopathy (frequency, 25\%-65\%; spontaneous resolution rate, 60\%-90\%). Stage II: bilateral hilar adenopathy and pulmonary infiltrates (frequency, 20\%-40\%; spontaneous resolution rate, $40 \%-70 \%$ ). Stage III: pulmonary infiltrates lacking hilar adenopathy (frequency, 10\%-15\%; spontaneous resolution rate, $10 \%-20 \%$ ). Stage IV: advanced pulmonary fibrosis (frequency, $5 \%$; spontaneous resolution rate, $0 \%$ ).

The decision to obtain biopsy samples hinges on the nature of clinical and radiologic findings (FIGURE 3). ${ }^{22,25,26}$

\section{Laboratory studies}

Multiple abnormalities may be seen in sarcoidosis, and specific lab tests may help support a diagnosis of sarcoidosis or detect organ-specific disease activity (TABLE 4). ${ }^{22,23,25,38}$ However, no consistently accurate biomarkers exist for use in clinical practice. An angiotensin-converting enzyme (ACE) level greater than 2 times the upper limit of normal may be helpful; however, sensitivity remains low, and genetic polymorphisms can influence the ACE level. ${ }^{25}$
Biomarkers sometimes used to assess disease activity are serum interleukin-2 receptor, neopterin, chitotriosidase, lysozyme, KL-6 glycoprotein, and amyloid A. ${ }^{21}$

\section{Additional tests to assess} specific features or organ involvement I Pulmonary function testing (PFT) is reviewed in detail below under "pulmonary sarcoidosis."

I Electrocardiogram (EKG)/transthoracic echocardiogram (TTE). EKG abnormalitiesconduction disturbances, arrhythmias, or nonspecific ST segment and T-wave changes-are the most common nonspecific findings. ${ }^{30}$ TTE findings are also nonspecific but 
TABLE 3

HRCT findings of sarcoidosis ${ }^{21,23,25,32}$

\begin{tabular}{|c|c|c|c|}
\hline HRCT findings & Frequency & Description & Location \\
\hline \multicolumn{4}{|l|}{ Potentially reversible } \\
\hline Lymphadenopathy & $80 \%$ & $\begin{array}{l}\text { Usually nonnecrotic, no mass effect }{ }^{21,32} \\
\text { Calcified in chronic involvement }{ }^{21}\end{array}$ & $\begin{array}{l}\text { Common: bilateral } \\
\text { hilar, mediastinal, right } \\
\text { paratracheal, subcarinal, } \\
\text { aortopulmonary }{ }^{32}\end{array}$ \\
\hline $\begin{array}{l}\text { Nodular and } \\
\text { reticulonodular pattern }\end{array}$ & $\begin{array}{l}90 \% \text { of } \\
\text { parenchymal } \\
\text { sarcoidosis }\end{array}$ & $\begin{array}{l}<10 \mathrm{~mm} \text { irregular nodules in subpleural region } \\
\text { along the bronchovascular and perilymphatic } \\
\text { distribution } \\
\text { Pathognomonic finding: irregular/beaded } \\
\text { appearance of vessels, airways, and septa due to } \\
\text { these nodules }{ }^{32} \\
\text { Isolated reticular pattern (rare) }\end{array}$ & $\begin{array}{l}\text { Predominantly in mid and } \\
\text { upper lung zones }\end{array}$ \\
\hline Ground-glass opacities & $16 \%-83 \%$ & Nonspecific feature $^{32}$; might suggest inflammation & \\
\hline Large nodules & $2.4 \%-4 \%$ & $\begin{array}{l}\text { Sarcoid nodules can aggregate into large pulmonary } \\
\text { mass with no coalescence in center (cluster sign) }\end{array}$ & \\
\hline Alveolar sarcoidosis & & $\begin{array}{l}\text { Air bronchograms with rarely massive consolidation } \\
\text { or cavitation }{ }^{23,32}\end{array}$ & \\
\hline Galaxy sign/cluster sign & & $\begin{array}{l}\text { Large pulmonary nodule surrounded by many small } \\
\text { satellite nodules }{ }^{23}\end{array}$ & \\
\hline $\begin{array}{l}\text { Mosaic attenuation } \\
\text { pattern and air trapping }\end{array}$ & & $\begin{array}{l}\text { Nonspecific feature which could mean small airway } \\
\text { involvement by granulomas or fibrosis }\end{array}$ & \\
\hline Mycetoma & $2 \%$ & $\begin{array}{l}\text { Fungal balls can develop in preexisting bullae or } \\
\text { cysts }^{32}\end{array}$ & \\
\hline Pleural effusion & $0.7 \%-10 \%$ & Very rare & More often on the right side \\
\hline Pneumothorax & $2-3 \%$ & & \\
\hline \multicolumn{4}{|l|}{ Irreversible } \\
\hline Fibrotic lung disease & $5 \%$ & $\begin{array}{l}\text { Fibrous bands, hilar retraction, traction } \\
\text { bronchiectasis, bullae, and irregular reticular } \\
\text { opacities, including interlobular lines and irregular } \\
\text { septal thickening, architectural distortion, } \\
\text { honeycomb cysts }{ }^{25,32}\end{array}$ & $\begin{array}{l}\text { Upper and middle lobes; } \\
\text { patchy distribution }\end{array}$ \\
\hline
\end{tabular}

HRCT, high-resolution computed tomography.

have value in assessing cardiac chamber size and function and myocardial involvement. TTE is indeed the most common screening modality for sarcoidosis-associated pulmonary hypertension (SAPH), which is definitively diagnosed by right heart catheterization (RHC). Further evaluation for cardiac sarcoidosis can be done with cardiac MRI or fluorodeoxyglucose PET in specialized settings.

I Lumbar puncture (LP) may reveal lymphocytic infiltration in suspected neurosarcoidosis, but the finding is nonspecific and can reflect infection or malignancy. Oligoclonal bands may also be seen in about one-third of neurosarcoidosis cases, and it is imperative to rule out multiple sclerosis. ${ }^{28}$

\section{Pulmonary sarcoidosis}

Pulmonary sarcoidosis accounts for most of the morbidity, mortality, and health care use associated with sarcoidosis. ${ }^{39,40}$

\section{Pathology of early and advanced pulmonary sarcoidosis}

Sarcoidosis is characterized by coalescing, tightly clustered, nonnecrotizing granulomas in the lung (FIGURE 4), most often located along the lymphatic routes of the pleura, in- 


\section{FIGURE 2}

\section{HRCT findings in sarcoidosis ${ }^{21,23,25,32}$}

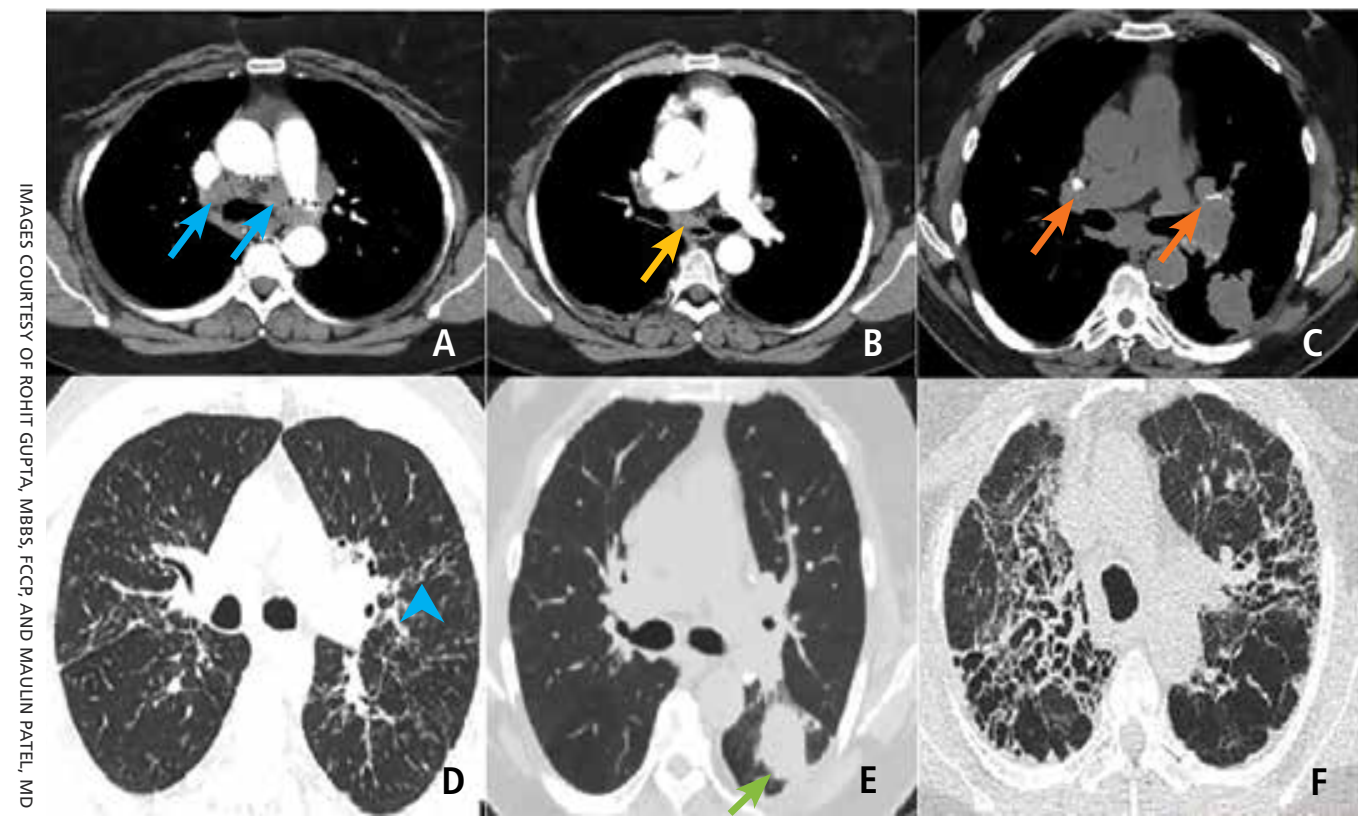

Shown here: enlarged lower paratracheal lymph nodes (A, blue arrows) and subcarinal nodes (B, yellow arrow); calcified bilateral hilar lymph nodes (C, orange arrows); multiple nodules along the peribronchovascular bundles (D, blue arrowhead shows an example); nodular mass in left lower lobe (E, green arrow [biopsy showed noncaseating granuloma with negative cultures]); honeycombing, traction bronchiectasis, and irregular reticulation in a patient with advanced pulmonary sarcoidosis (F).

HRCT, high-resolution computed tomography.

terlobular septa, and bronchovascular bundles. ${ }^{41}$ Granulomas contain epithelioid cells or multinucleated giant cells surrounded by a chronic lymphocytic infiltrate. Typically, intracytoplasmic inclusions, such as Schaumann bodies, asteroid bodies, and blue bodies of calcium oxalates are noted within giant cells.

In chronic disease, lymphocytic infiltrate vanishes and granulomas tend to become increasingly fibrotic and enlarge to form hyalinized nodules rich with densely eosinophilic collagen. In $10 \%$ to $30 \%$ of cases, the lungs undergo progressive fibrosis. ${ }^{40}$ Nonresolving inflammation appears to be the major cause of fibrosis and the peribronchovascular localization leading to marked bronchial distortion.

\section{Clinical features, monitoring, and outcomes}

Pulmonary involvement occurs in most patients with sarcoidosis, and subclinical pulmonary disease is generally present, even when extrathoracic manifestations predominate. ${ }^{23}$ Dry cough, dyspnea, and chest discomfort are the most common symptoms. Chest auscultation is usually unremarkable. Wheezing is more common in those with fibrosis and is attributed to airway-centric fibrosis. ${ }^{42}$ There is often a substantial delay between the onset of symptoms and the diagnosis of pulmonary sarcoidosis, as symptoms are nonspecific and might be mistaken for more common pulmonary diseases, such as asthma or chronic bronchitis. ${ }^{43}$

Since sarcoidosis can affect pulmonary parenchyma, interstitium, large and small airways, pulmonary vasculature, and respiratory muscles, the pattern of lung function impairment on PFT varies from normal to obstruction, restriction, isolated diffusion defect, or a combination of these. The typical physiologic abnormality is a restrictive ventilatory defect with a decreased diffusing capacity of the lung for carbon monoxide (DLCO). Extent of disease seen on HRCT 
FIGURE 3

\section{Diagnostic algorithm for suspected sarcoidosis ${ }^{22,25,26}$}

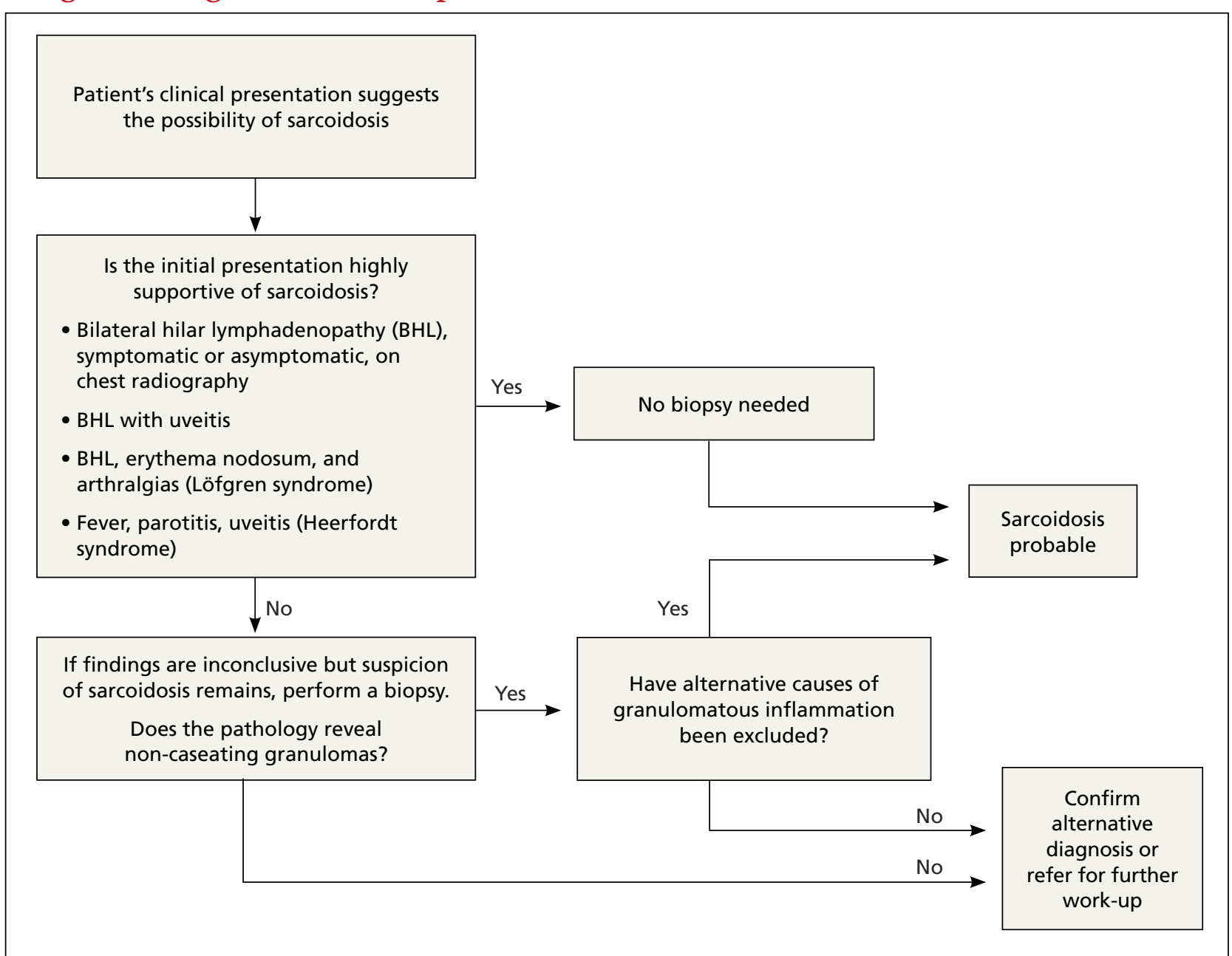

correlates with level of restriction. ${ }^{44}$ Airway obstruction can be multifactorial and due to airway distortion (more likely to occur in fibrotic lung disease) and luminal disease. ${ }^{45-48}$ The 6-minute walk test and DLCO can also aid in the diagnosis of SAPH and advanced parenchymal lung disease.

While monitoring is done clinically and with testing (PFT and imaging) as needed, the optimal approach is unclear. Nevertheless, longitudinal monitoring with testing may provide useful management and prognostic information. ${ }^{40}$ Pulmonary function can remain stable in fibrotic sarcoidosis over extended periods and actually can improve in some patients. ${ }^{49}$ Serial spirometry, particularly forced vital capacity, is the most reliable tool for monitoring; when a decline in measurement occurs, chest radiography can elucidate the mechanism. ${ }^{50,51}$

Because sarcoidosis is a multisystem disease, caution needs to be exercised when evaluating a patient's new or worsening respiratory symptoms to accurately determine the cause of symptoms and direct therapy accordingly. In addition to refractory inflammatory pulmonary disease, airway disease, infection, fibrosis, and SAPH, one needs to consider extrapulmonary involvement or complications such as cardiac or neurologic disease, musculoskeletal disease, depression, or fatigue. Adverse medication effects, deconditioning, or unrelated (or possibly related) disorders (eg pulmonary embolism) may be to blame. 
FIGURE 4

Sarcoidosis is characterized by coalescing, tightly clustered, nonnecrotizing granulomas in the affected organ

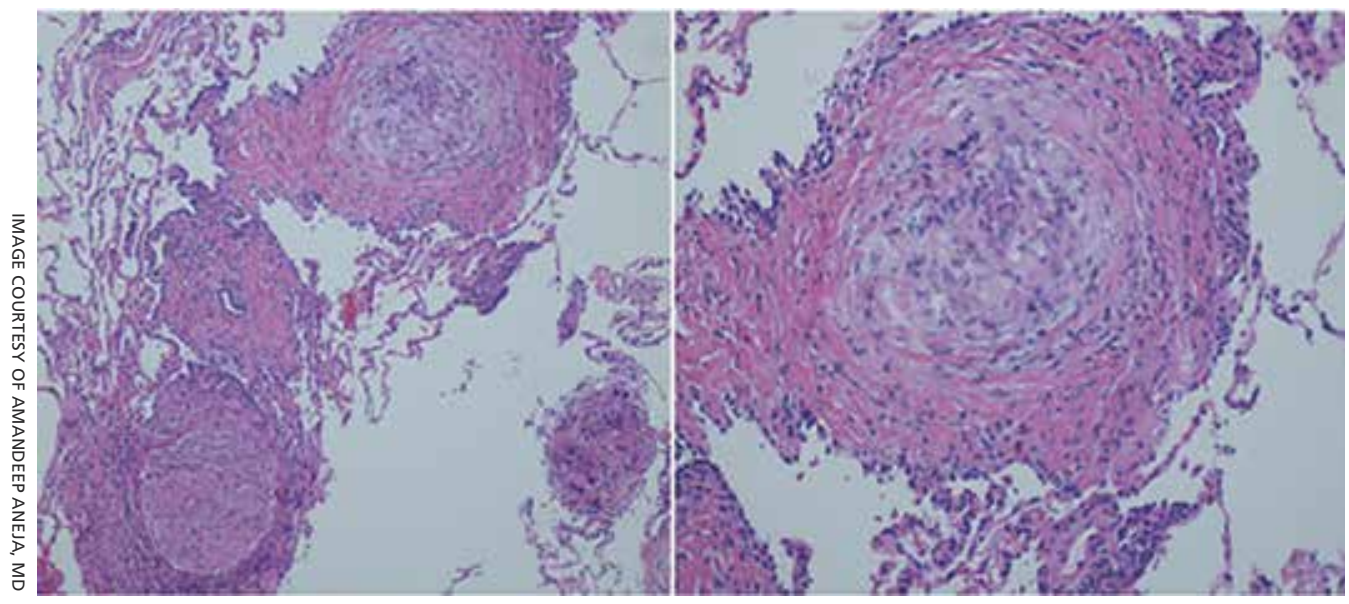

The panel on the left shows well-formed nonnecrotizing granulomas within the pulmonary interstitium. On high power, nonnecrotizing granuloma with surrounding fibrosis is seen on the right panel.

TABLE 4

\section{Laboratory studies that point to organ/system involvement} in sarcoidosis $22,23,25,38$

\begin{tabular}{|c|c|c|}
\hline Laboratory studies & Abnormality & Organ/system involvement \\
\hline Complete blood count ${ }^{22,23}$ & Anemia, leukopenia & Bone marrow, spleen \\
\hline C-reactive protein 25 & Elevated & $\begin{array}{l}\text { Löfgren syndrome, necrotizing sarcoid } \\
\text { granuloma }\end{array}$ \\
\hline Creatinine & Elevated & Kidney \\
\hline Calcium 22 & Elevated & Calcium dysregulation \\
\hline Liver function test ${ }^{38}$ & $\begin{array}{l}\text { Alkaline phosphatase elevation, } \\
\text { transaminitis }\end{array}$ & Liver \\
\hline $\begin{array}{l}\text { N-terminal pro brain natriuretic peptide } \\
(\mathrm{NT}-\text { proBNP) }\end{array}$ & Elevated & Heart, pulmonary hypertension \\
\hline
\end{tabular}

\section{Determining prognosis}

Prognosis of sarcoidosis varies and depends on epidemiologic factors, clinical presentation, and course, as well as specific organ involvement. Patients may develop lifethreatening pulmonary, cardiac, or neurologic complications. End-stage disease may require organ transplantation for eligible patients.

Most patients with pulmonary sarcoidosis experience clinical remission with minimal residual organ impairment and a favorable long-term outcome. Advanced pulmonary disease (known as APS) occurs in a small proportion of patients with sarcoidosis but accounts for most of the poor outcomes in sarcoidosis. ${ }^{40}$ APS is variably defined, but it generally includes pulmonary fibrosis, SAPH, and respiratory infection.

One percent to $5 \%$ of patients with sarcoidosis die from complications, and mortality is higher in women and African Americans. ${ }^{52}$ Mortality and morbidity may be increasing. ${ }^{53}$ The reasons behind these trends are unclear but could include true increases in disease incidence, better detection rates, greater severity of disease, or an aging population. Increased hospitalizations and health care use might be due to organ damage from granulomatous 
TABLE 5

Anti-inflammatory therapy used in sarcoidosis ${ }^{58,64,67-81}$

\begin{tabular}{|c|c|c|}
\hline Drug (usual dose) & Comments & Adverse effects \\
\hline $\begin{array}{l}\text { Corticosteroids } \\
(20-40 \text { mg PO daily })^{58,64,72,73}\end{array}$ & First-line treatment & $\begin{array}{l}\text { Diabetes, hypertension, weight gain, bone loss, } \\
\text { cataracts, glaucoma, infection }\end{array}$ \\
\hline $\begin{array}{l}\text { Methotrexate } \\
\left(5-15 \text { mg PO/SQ weekly) }{ }^{67}\right.\end{array}$ & $\begin{array}{l}\text { First choice for second-line treatment } \\
\text { of sarcoidosis }\end{array}$ & $\begin{array}{l}\text { Bone marrow suppression, kidney failure, } \\
\text { hepatotoxicity, pneumonitis, gastrointestinal } \\
\text { toxicity, lymphoma }\end{array}$ \\
\hline $\begin{array}{l}\text { Azathioprine } \\
(50-200 \mathrm{mg} \text { PO daily })^{68}\end{array}$ & $\begin{array}{l}\text { Similar efficacy as methotrexate, but increased } \\
\text { risk of infection }\end{array}$ & Leukopenia, nausea, infection \\
\hline $\begin{array}{l}\text { Mycophenolate mofetil } \\
(500-3000 \text { mg PO daily })^{74,75}\end{array}$ & $\begin{array}{l}\text { More effective than other antimetabolites for } \\
\text { treatment of chronic ocular inflammation } \\
\text { Can be used in patients with kidney dysfunction }\end{array}$ & Nausea, diarrhea, opportunistic infection \\
\hline $\begin{array}{l}\text { Leflunomide } \\
(10-20 \mathrm{mg} \text { PO daily })^{69,76}\end{array}$ & $\begin{array}{l}\text { Synergistic effect with methotrexate } \\
\text { Less effective for musculoskeletal and neurologic } \\
\text { involvement } \\
\text { Effective for cutaneous, ocular, and sinonasal } \\
\text { involvement }\end{array}$ & $\begin{array}{l}\text { Leukopenia, hepatotoxic effects, infection, } \\
\text { alopecia }\end{array}$ \\
\hline $\begin{array}{l}\text { TNF-alpha inhibitors: } \\
\text { infliximab, } \\
\text { adalimumab }\end{array}$ & $\begin{array}{l}\text { Third-line treatment indications: } \\
\text { - failed treatment with steroids and } \\
\text { antimetabolites } \\
\text { - chronic pulmonary disease with decreased FVC } \\
\text { and FEV } 1 \\
\text { - lupus pernio } \\
\text { - neuro- and cardiac sarcoidosis }\end{array}$ & $\begin{array}{l}\text { Injection site reaction, neutropenia, } \\
\text { TB reactivation, infection, sarcoid- } \\
\text { like granulomatosis, heart failure, and } \\
\text { demyelinating disease }\end{array}$ \\
\hline Rituximab $^{78,79}$ & Has shown effectiveness in ocular sarcoidosis & $\begin{array}{l}\text { HBV reactivation, multifocal } \\
\text { leukoencephalopathy, peripheral edema, rash, } \\
\text { angioedema, hepatotoxicity, neuropathy }\end{array}$ \\
\hline $\begin{array}{l}\text { Levofloxacin, ethambutol, } \\
\text { azithromycin, and rifampin } \\
\text { (CLEAR) }^{80,81}\end{array}$ & Persistent cutaneous and pulmonary sarcoidosis & Leukopenia, arthralgia, insomnia, rash \\
\hline
\end{tabular}

CLEAR, concomitant levofloxacin, ethambutol, azithromycin, and rifampin regimen; FEV ${ }_{1}$, forced expiratory volume in 1 second; FVC, forced vital capacity; HBV, hepatitis $B$ virus; TB, tuberculosis.

inflammation (and resultant fibrosis), complications associated with treatment, and psychosocial effects of the disease/treatment.

\section{Management}

Management consists primarily of antiinflammatory or immunosuppressive therapies but can also include measures to address specific complications (such as fatigue) and organ transplant, as well as efforts to counter adverse medication effects. Other supportive and preventive measures may include, on a case-by-case basis, oxygen supplementation, vaccinations, or pulmonary rehabilitation.
Details of these are found in other, more indepth reviews on treatment; we will briefly review anti-inflammatory therapy, which forms the cornerstone of treatment in most patients with sarcoidosis.

I General approach to treatment decisions. Anti-inflammatory therapy is used to reduce granulomatous inflammation, thereby preserving organ function and reducing symptoms. A decision to begin treatment is one shared with the patient and is based on symptoms and potential danger of organ system failure. ${ }^{54}$ Patients who are symptomatic or have progressive disease or physiologic impairment are generally candidates for 
treatment. Monitoring usually suffices for those who have minimal symptoms, stable disease, and preserved organ function.

Patients with pulmonary sarcoidosis at CXR stage 0 should not receive treatment, given that large, randomized trials have shown no meaningful benefit and that these patients have a high likelihood of spontaneous remission and excellent long-term prognosis. ${ }^{55-58}$ However, a subgroup of patients classified as stage $0 / \mathrm{I}$ on CXR may show parenchymal disease on HRCT, ${ }^{59}$ and, if more symptomatic, could be considered for treatment. For patients with stage II to IV pulmonary sarcoidosis with symptoms, there is good evidence that treatment may improve lung function and reduce dyspnea and fatigue..$^{57,60-62}$

Corticosteroids are first-line treatment for most patients. Based on expert opinion, treatment of pulmonary sarcoidosis is generally started with oral prednisone (or an equivalent corticosteroid). A starting dose of 20 to $40 \mathrm{mg} / \mathrm{d}$ generally is sufficient for most patients. If the patient responds to initial treatment, prednisone dose is tapered over a period of months. If symptoms worsen during tapering, the minimum effective dose is maintained without further attempts at tapering. Treatment is continued for at least 3 to 6 months but it might be needed for longer durations; unfortunately, evidence-based guidelines are lacking. ${ }^{63}$ Once the patient goes into remission, close monitoring is done for possible relapses. Inhaled corticosteroids alone have not reduced symptoms or improved lung function in patients with pulmonary sarcoidosis. ${ }^{64-66}$

ISteroid-sparing agents are added for many patients. For patients receiving chronic prednisone therapy ( $\geq 10 \mathrm{mg}$ for $>6$ months), steroid-sparing agents are considered to minimize the adverse effects of steroids or to better control the inflammatory activity of sarcoidosis. These agents must be carefully selected, and clinical and laboratory monitoring need to be done throughout therapy. TABLE $5^{58,64,67-81}$ shows the major anti-inflammatory treatment agents used for sarcoidosis.

The management might be complicated for extrapulmonary, multi-organ, and advanced sarcoidosis (advanced pulmonary sarcoidosis, cardiac disease, neurosarcoid- osis, lupus pernio, etc) when specialized testing, as well as a combination of corticosteroids and steroid-sparing agents (with higher doses or prolonged courses), might be needed. This should be performed at an expert sarcoidosis center, ideally in a multidisciplinary setting involving pulmonologists and/or rheumatologists, chest radiologists, and specialists as indicated, based on specific organ involvement.

\section{Research and future directions}

Key goals for research are identifying more accurate biomarkers of disease, improving diagnosis of multi-organ disease, determining validated endpoints of clinical trials in sarcoidosis, and developing treatments for refractory cases.

There is optimism and opportunity in the field of sarcoidosis overall. An example of an advancement is in the area of APS, as the severity and importance of this phenotype has been better understood. Worldwide registries and trials of pulmonary vasodilator therapy (bosentan, sildenafil, epoprostenol, and inhaled iloprost) in patients with SAPH without left ventricular dysfunction are promising. ${ }^{82-85}$ However, no benefit in survival has been shown.

RioSAPH is a double-blind, placebocontrolled trial of Riociguat (a stimulator of soluble guanylate cyclase) for SAPH (NCT02625558) that is closed to enrollment and undergoing data review. Similarly, results of the phase IV study of pirfenidone, an antifibrotic agent that was shown to decrease disease progression and deaths in idiopathic pulmonary fibrosis, ${ }^{86}$ are awaited in the near future.

Other potential directions being explored are multicenter patient registries and randomized controlled trials, analyses of existing databases, use of biobanking, and patient-centered outcome measures. Hopefully, the care of patients with sarcoidosis will become more evidence based with ongoing and upcoming research in this field. JFP

\section{CORRESPONDENCE}

Rohit Gupta, MBBS, FCCP, 3401 North Broad Street,

7 Parkinson Pavilion, Philadelphia, PA 19140;

rohit.gupta@tuhs.temple.edu 


\section{References}

1. Costabel U, Hunninghake G. ATS/ERS/WASOG statement on sarcoidosis. Sarcoidosis Statement Committee. American Thoracic Society. European Respiratory Society. World Association for Sarcoidosis and Other Granulomatous Disorders. Eur Respir J. 1999;14:735-737.

2. Hillerdal G, Nöu E, Osterman K, et al. Sarcoidosis: epidemiology and prognosis. A 15-year European study. Am Rev Respir Dis. 1984;130:29-32.

3. Mirsaeidi M, Machado RF, Schraufnagel D, et al. Racial difference in sarcoidosis mortality in the United States. Chest. 2015;147: 438-449.

4. Rybicki BA, Iannuzzi MC, Frederick MM, et al. Familial aggregation of sarcoidosis. A case-control etiologic study of sarcoidosis (ACCESS). Am J Resp Crit Care Med. 2001;164:2085-2091.

5. Sverrild A, Backer V, Kyvik KO, et al. Heredity in sarcoidosis: a registry-based twin study. Thorax. 2008;63:894.

6. Vuyst P, Dumortier P, Schandené L, et al. Sarcoidlike lung granulomatosis induced by aluminum dusts. Am Rev Respir Dis. 1987;135:493-497.

7. Werfel U, Schneider J, Rödelsperger K, et al. Sarcoid granulomatosis after zirconium exposure with multiple organ involvement. European Respir J. 1998;12:750.

8. Newman KL, Newman LS. Occupational causes of sarcoidosis. Curr Opin Allergy Clin Immunol. 2012;12:145-150.

9. Zissel G, Müller-Quernheim J. Specific antigen(s) in sarcoidosis: a link to autoimmunity? Eur Respir J. 2016;47:707-709.

10. Chen ES, Moller DR. Etiology of sarcoidosis. Clin Chest Med. 2008;29:365-377.

11. Agostini C, Adami F, Semenzato G. New pathogenetic insight into the sarcoid granuloma. Curr Opin Rheumatol. 2000;12:71-76.

12. Valentonyte R, Hampe J, Huse K, et al. Sarcoidosis is associated with a truncating splice site mutation in BTNL2. Nat Genet. 2005;37:357-364.

13. Rybicki BA, Walewski JL, Maliarik MJ, et al. The BTNL2 gene and sarcoidosis susceptibility in African Americans and Whites. Am J Hum Genet. 2005;77:491-499.

14. Newman LS, Rose CS, Bresnitz EA, et al. A case control etiologic study of sarcoidosis: environmental and occupational risk factors. Am J Respir Crit Care Med. 2004;170:1324-1330.

15. Gorham ED, Garland CF, Garland FC, et al. Trends and occupational associations in incidence of hospitalized pulmonary sarcoidosis and other lung diseases in Navy personnel: a 27-year historical prospective study, 1975-2001. Chest. 2004;126:1431-1438.

16. Kucera GP, Rybicki BA, Kirkey KL, et al. Occupational risk factors for sarcoidosis in African-American siblings. Chest. 2003;123:1527-1535.

17. Prezant DJ, Dhala A, Goldstein A, et al. The incidence, prevalence, and severity of sarcoidosis in New York City firefighters. Chest. 1999;116:1183-1193.

18. Barnard J, Rose C, Newman L, et al. Job and industry classifications associated with sarcoidosis in A Case-Control Etiologic Study of Sarcoidosis (ACCESS). J Occup Environ Med. 2005;47:226-234.

19. Izbicki G, Chavko R, Banauch GI, et al. World Trade Center "sarcoid-like" granulomatous pulmonary disease in New York City Fire Department rescue workers. Chest. 2007;131:1414-1423.

20. Eishi Y, Suga M, Ishige I, et al. Quantitative analysis of mycobacterial and propionibacterial DNA in lymph nodes of Japanese and European patients with sarcoidosis. J Clin Microbiol. 2002;40: 198-204.

21. Valeyre D, Prasse A, Nunes $\mathrm{H}$, et al. Sarcoidosis. Lancet. 2014;383:1155-1167.

22. Crouser ED, Maier LA, Wilson KC, et al. Diagnosis and detection of sarcoidosis. An official American Thoracic Society clinical practice guideline. Am J Respir Crit Care Med. 2020;201:e26-51.

23. Judson MA, ed. Pulmonary Sarcoidosis: A Guide for the Practicing Clinician. Springer; 2014.

24. Govender P, Berman JS. The diagnosis of sarcoidosis. Clin Chest Med. 2015;36:585-602.

25. Valeyre D, Bernaudin J-F, Uzunhan Y, et al. Clinical presentation of sarcoidosis and diagnostic work-up. Semin Resp Crit Care Med. 2014;35:336-351.

26. Judson MA. The clinical features of sarcoidosis: a comprehensive review. Clin Rev Allergy Immunol. 2015;49:63-78.

27. Wanat KA, Rosenbach M. Cutaneous sarcoidosis. Clin Chest Med.
2015;36:685-702.

28. Culver DA, Neto ML, Moss BP, et al. Neurosarcoidosis. Semin Resp Crit Care Med. 2017;38:499-513.

29. Pasadhika S, Rosenbaum JT. Ocular sarcoidosis. Clin Chest Med. 2015;36:669-683.

30. Sayah DM, Bradfield JS, Moriarty JM, et al. Cardiac involvement in sarcoidosis: evolving concepts in diagnosis and treatment. Semin Resp Crit Care Med. 2017;38:477-498.

31. Baughman RP, Teirstein AS, Judson MA, et al. Clinical characteristics of patients in a case control study of sarcoidosis. Am J Resp Crit Care. 2012;164:1885-1889.

32. Keijsers RG, Veltkamp M, Grutters JC. Chest imaging. Clin Chest Med. 2015;36:603-619.

33. Scadding J. Prognosis of intrathoracic sarcoidosis in England. A review of 136 cases after five years' observation. Brit Med J. 1961;2:1165-1172.

34. Miller B, Putman C. The chest radiograph and sarcoidosis. Reevaluation of the chest radiograph in assessing activity of sarcoidosis: a preliminary communication. Sarcoidosis. 1985;2:85-90.

35. Loddenkemper R, Kloppenborg A, Schoenfeld N, et al. Clinical findings in 715 patients with newly detected pulmonary sarcoid osis--results of a cooperative study in former West Germany and Switzerland. WATL Study Group. Wissenschaftliche Arbeitsgemeinschaft für die Therapie von Lungenkrankheitan. Sarcoidosis Vasc Diffuse Lung Dis. 1998;15:178-182.

36. Calandriello L, Walsh SLF. Imaging for sarcoidosis. Semin Resp Crit Care Med. 2017;38:417-436.

37. Gupta D, Dadhwal DS, Agarwal R, et al. Endobronchial ultrasound-guided transbronchial needle aspiration vs conventional transbronchial needle aspiration in the diagnosis of sarcoidosis. Chest. 2014;146:547-556.

38. Baydur A. Recent developments in the physiological assessment of sarcoidosis: clinical implications. Curr Opin Pulm Med. 2012;18:499-505.

39. Jamilloux Y, Maucort-Boulch D, Kerever S, et al. Sarcoidosisrelated mortality in France: a multiple-cause-of-death analysis. Eur Respir J. 2016;48:1700-1709.

40. Gupta R, Baughman RP. Advanced pulmonary sarcoidosis. Semin Respir Crit Care Med. 2020;41:700-715.

41. Rossi G, Cavazza A, Colby TV. Pathology of sarcoidosis. Clin Rev Allergy Immunol. 2015;49:36-44.

42. Hansell D, Milne D, Wilsher M, et al. Pulmonary sarcoidosis morphologic associations of airflow obstruction at thin-section CT. Radiology. 1998;209:697-704.

43. Judson MA, Thompson BW, Rabin DL, et al. The diagnostic pathway to sarcoidosis. Chest. 2003;123:406-412.

44. Müller NL, Mawson JB, Mathieson JR, et al. Sarcoidosis: correlation of extent of disease at CT with clinical, functional, and radiographic findings. Radiology. 1989;171:613-618.

45. Harrison BDW, Shaylor JM, Stokes TC, et al. Airflow limitation in sarcoidosis-a study of pulmonary function in 107 patients with newly diagnosed disease. Resp Med. 1991;85:59-64.

46. Polychronopoulos VS, Prakash UBS. Airway Involvement in sarcoidosis. Chest. 2009;136:1371-1380.

47. Chambellan A, Turbie P, Nunes H, et al. Endoluminal stenosis of proximal bronchi in sarcoidosis: bronchoscopy, function, and evolution. Chest. 2005;127:472-481.

48. Handa T, Nagai S, Fushimi Y, et al. Clinical and radiographic indices associated with airflow limitation in patients with sarcoidosis. Chest. 2006;130:1851-1856.

49. Nardi A, Brillet P-Y, Letoumelin P, et al. Stage IV sarcoidosis: com parison of survival with the general population and causes of death. Eur Respir J. 2011;38:1368-1373.

50. Zappala CJ, Desai SR, Copley SJ, et al. Accuracy of individual variables in the monitoring of long-term change in pulmonary sarcoidosis as judged by serial high-resolution CT scan data. Chest 2014;145:101-107.

51. Gafà G, Sverzellati N, Bonati E, et al. Follow-up in pulmonary sarcoidosis: comparison between HRCT and pulmonary function tests. Radiol Med.2012;117:968-978.

52. Gerke AK. Morbidity and mortality in sarcoidosis. Curr Opin Pulm Med. 2014;20:472-478.

53. Kearney GD, Obi ON, Maddipati V, et al. Sarcoidosis deaths in the United States: 1999-2016. Respir Med. 2019;149:30-35.

54. Baughman RP, Judson M, Wells A. The indications for the treat- 
ment of sarcoidosis: Wells Law. Sarcoidosis Vasc Diffuse Lung Dis. 2017;34:280-282.

55. Nagai S, Shigematsu M, Hamada K, et al. Clinical courses and prognoses of pulmonary sarcoidosis. Curr Opin Pulm Med. 1999;5:293-298.

56. Neville E, Walker AN, James DG. Prognostic factors predicting the outcome of sarcoidosis: an analysis of 818 patients. Q J Med. 1983;52:525-533.

57. Bradley B, Branley HM, Egan JJ, et al. Interstitial lung disease guideline: the British Thoracic Society in collaboration with the Thoracic Society of Australia and the Irish Thoracic Society. Thorax. 2008;63(suppl 5):v1-v58.

58. Pietinalho A, Tukiainen P, Haahtela T, et al. Oral prednisolone followed by inhaled budesonide in newly diagnosed pulmonary sarcoidosis: a double-blind, placebo-controlled multicenter study. Finnish Pulmonary Sarcoidosis Group. Chest. 1999;116:424-431.

59. Oberstein A, von Zitzewitz H, Schweden F, et al. Non invasive evaluation of the inflammatory activity in sarcoidosis with highresolution computed tomography. Sarcoidosis Vasc Diffuse Lung Dis. 1997;14:65-72.

60. Gibson G, Prescott RJ, Muers MF, et al. British Thoracic Society Sarcoidosis study: effects of long term corticosteroid treatment. Thorax. 1996;51:238-247.

61. Baughman RP, Nunes H. Therapy for sarcoidosis: evidence-based recommendations. Expert Rev Clin Immunol. 2012;8:95-103.

62. Pietinalho A, Tukiainen P, Haahtela T, et al. Early treatment of stage II sarcoidosis improves 5 -year pulmonary function. Chest. 2002;121:24-31.

63. Rahaghi FF, Baughman RP, Saketkoo LA, et al. Delphi consensus recommendations for a treatment algorithm in pulmonary sarcoidosis. Eur Respir Rev. 2020;29:190146.

64. Baughman RP, Iannuzzi MC, Lower EE, et al. Use of fluticasone in acute symptomatic pulmonary sarcoidosis. Sarcoidosis Vasc Diffuse Lung Dis. 2002;19:198-204.

65. du Bois RM, Greenhalgh PM, Southcott AM, et al. Randomized trial of inhaled fluticasone propionate in chronic stable pulmonary sarcoidosis: a pilot study. Eur Respir J. 1999;13:1345-1350.

66. Milman N, Graudal N, Grode G, Munch E. No effect of high-dose inhaled steroids in pulmonary sarcoidosis: a double-blind, placebo-controlled study. J Intern Med. 1994;236:285-290.

67. Baughman RP, Winget DB, Lower EE. Methotrexate is steroid sparing in acute sarcoidosis: results of a double blind, randomized trial. Sarcoidosis Vasc Diffuse Lung Dis. 2000;17:60-66.

68. Vorselaars ADM, Wuyts WA, Vorselaars VMM, et al. Methotrexate vs azathioprine in second-line therapy of sarcoidosis. Chest. 2013;144:805-812.

69. Sahoo D, Bandyopadhyay D, Xu M, et al. Effectiveness and safety of leflunomide for pulmonary and extrapulmonary sarcoidosis. Eur Respir J. 2011;38:1145-1150.

70. Baughman RP, Drent M, Kavuru M, et al. Infliximab therapy in patients with chronic sarcoidosis and pulmonary involvement. $A m$
J Resp Crit Care Med. 2006;174:795-802.

71. Rossman MD, Newman LS, Baughman RP, et al. A double-blinded, randomized, placebo-controlled trial of infliximab in subjects with active pulmonary sarcoidosis. Sarcoidosis Vasc Diffuse Lung Dis. 2006;23:201-208.

72. Selroos O, Sellergren T. Corticosteroid therapy of pulmonary sarcoidosis. A prospective evaluation of alternate day and daily dosage in stage II disease. Scand J Respir Dis. 1979;60:215-221.

73. Israel HL, Fouts DW, Beggs RA. A controlled trial of prednisone treatment of sarcoidosis. Am Rev Respir Dis. 1973;107: 609-614.

74. Hamzeh N, Voelker A, Forssén A, et al. Efficacy of mycophenolate mofetil in sarcoidosis. Respir Med. 2014;108:1663-1669.

75. Brill A-K, Ott SR, Geiser T. Effect and safety of mycophenolate mofetil in chronic pulmonary sarcoidosis: a retrospective study. Respiration. 2013;86:376-383.

76. Baughman RP, Lower EE. Leflunomide for chronic sarcoidosis Sarcoidosis Vasc Diffuse Lung Dis. 2004;21:43-48.

77. Sweiss NJ, Noth I, Mirsaeidi M, et al. Efficacy results of a 52-week trial of adalimumab in the treatment of refractory sarcoidosis. Sarcoidosis Vasc Diffuse Lung Dis. 2014;31:46-54.

78. Sweiss NJ, Lower EE, Mirsaeidi M, et al. Rituximab in the treatment of refractory pulmonary sarcoidosis. Eur Respir J. 2014;43:1525-1528.

79. Thatayatikom A, Thatayatikom S, White AJ. Infliximab treatment for severe granulomatous disease in common variable immunodeficiency: a case report and review of the literature. Ann Allergy Asthma Immunol. 2005;95:293-300.

80. Drake WP, Oswald-Richter K, Richmond BW, et al. Oral antimycobacterial therapy in chronic cutaneous sarcoidosis: a randomized, single-masked, placebo-controlled study. Jama Dermatol. 2013;149:1040-1049.

81. Drake WP, Richmond BW, Oswald-Richter K, et al. Effects of broad-spectrum antimycobacterial therapy on chronic pulmonary sarcoidosis. Sarcoidosis Vasc Diffuse Lung Dis. 2013;30: 201-211.

82. Baughman RP, Culver DA, Cordova FC, et al. Bosentan for sarcoidosis-associated pulmonary hypertension: a double-blin placebo controlled randomized trial. Chest. 2014;145:810-817.

83. Baughman RP, Shlobin OA, Wells AU, et al. Clinical features of sarcoidosis associated pulmonary hypertension: results of a multinational registry. Respir Med. 2018;139:72-78.

84. Fisher KA, Serlin DM, Wilson KC, et al. Sarcoidosis-associated pulmonary hypertension outcome with long-term epoprosteno treatment. Chest. 2006;130:1481-1488.

85. Baughman RP, Judson MA, Lower EE, et al. Inhaled iloprost for sarcoidosis associated pulmonary hypertension. Sarcoidosis Vasc Diffuse Lung Dis. 2009;26:110-120.

86. King TE, Bradford WZ, Castro-Bernardini S, et al. A phase 3 tria of pirfenidone in patients with idiopathic pulmonary fibrosis. N Engl J Med. 2014;370:2083-2092. 